\title{
Crime e castigo nos modos de "fazer justiça": um estudo sobre representações sociais da criminalidade urbana, punição e justiça
}

Guilherme Almeida Borges

Curso: Mestrado em Sociologia

Data da defesa: 18 de agosto de 2009

Orientadora: Prof ${ }^{\mathrm{a}} \mathrm{Dr}^{\mathrm{a}}$ Maria Stela Grossi Porto

\section{Resumo}

As percepções, valores e representações formuladas sobre a criminalidade urbana e a forma de combatê-la consistem no objeto central da pesquisa empreendida. A categoria central a partir da qual a pesquisa se estruturou é a que aqui se está denominando "fazer justiça". Diz respeito a arranjos discursivos difusos encontrados na população civil que reivindica que, frente à criminalidade, a Justiça seja feita. Esses discursos demonstram a forma como a população interpreta determinados princípios de Justiça ante a realidade na qual vive.

Foram pesquisadas pessoas que tiveram contato com o crime violento na condição de vítimas, parentes de vítimas ou testemunhas dos crimes. Por meio do contato com a instituição policial, foram realizadas observações nas delegacias de polícia do Distrito Federal, no intuito de buscar contato com vítimas de crimes violentos e analisar a forma como seus discursos eram gerados e estruturados após o crime ter acontecido. As localidades pesquisadas foram escolhidas a partir de uma categorização das diversas Regiões Administrativas do Distrito Federal de acordo com suas características socioeconômicas. Foram pesquisados o Lago Sul e o Plano Piloto como regiões cuja população possui perfil socioeconômico próximo e poder aquisitivo 
mais alto e a Ceilândia e o Paranoá, como áreas representativas das localidades com poder aquisitivo mais baixo.

Para a análise dos discursos sobre "fazer justiça" foi utilizada a teoria das representações sociais no intuito de buscar o quadro cognitivo e as lógicas que davam subsídio a uma interpretação do crime e das formas de combatê-lo. A análise das representações sociais do crime e do "fazer justiça" buscam evidenciar os moldes cognitivos que formam a experiência do crime como uma ordenação dos fatos vividos, de forma que adquiram sentido para a população. $\mathrm{O}$ "fazer justiça", mais do que uma série de discursos, representa uma forma de interpretar a realidade vivida e representar o crime, o criminoso e a criminalidade urbana.

Palavras-chave: fazer justiça; crime; justiça; representações sociais. 